\title{
In vitro fertilization: Perceptions and misperceptions among women of reproductive age group in Sokoto, Nigeria
}

Oche M. Oche ${ }^{1,2^{*}}$, Jessica T. Ango ${ }^{2}$, Godwin J. Gana ${ }^{2}$, Remi A. Oladigbolu², Nneka C. Okafoagu², Abubakar S. Umarr,2, Fatima A. Adam², Ogunyemi J. Oluwatobi² and Abdulazeez M. Gatawa²

*Correspondence: ochedr@hotmail.com

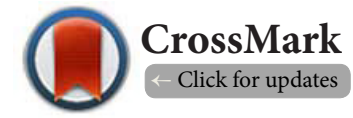

'Department of Community Health, College of Health Sciences, Usmanu Danfodiyo University, Sokoto.

${ }^{2}$ Department of Community Medicine, Usmanu Danfodiyo University Teaching Hospital, Sokoto.

\begin{abstract}
Background: Infertility is a global issue causing a lot of psychological and social problems among couples. In Vitro Fertilization (IVF) is one of the options available for couples who want children but cannot have them. This study aims to assess the level of awareness, perceptions and misconceptions of IVF among women of reproductive age group (WRAG) in Sokoto metropolis in north-western Nigeria.

Methods: This was a cross sectional descriptive study involving 306 WRAG who were recruited using multistage sampling technique. Semi structured interviewer administered questionnaires was used and the data collected was analyzed using IBM SPSS version 20.level of statistical significance was set ay p=0.05.

Results: The mean age of the respondents was a $26.7 \pm 6.85$ year with less than half of the respondents having no living children. Majority, (74.2\%) of the respondents were aware of and had a positive perception $(69 \%)$ towards IVF. About $54 \%$ (157) of those who did not accept IVF gave religion and the high cost of the procedure as reasons for rejecting it. Fifty one percent of the respondents were willing to use In Vitro Fertilization if the need arose. Religion $\left(\chi^{2}=4.726 ; \mathrm{df}=1 ; \mathrm{p}<0.04\right)$ and awareness of the availability of IVF services $\left(\chi^{2}=5.393 ; \mathrm{df}=1 ; \mathrm{p}<0.023\right)$ were factors associated with the willingness to utilize IVF.

Conclusion: The respondents had good level of awareness and positive perception about IVF, with few of them willing to utilize it. Awareness of the availability of IVF services and religious beliefs were factors that influenced respondents' willingness to utilize IVF services. Health care providers should try to explore ways to sensitize community, religious and traditional leaders in order to improve the attitude of the populace towards IVF service utilisation.
\end{abstract}

Keywords: In Vitro Fertilization, Women of reproductive age group, Perception, Misperception

\section{Introduction}

Infertility is the inability to conceive children after one year of unprotected intercourse [1]. Infertility is a global issue and its prevalence is on the increase worldwide, particularly in Africa as reported from several African societies it is mostly attributed to tubal occlusion. It accounts for over $50 \%$ of cases reported in gynaecology clinics in the developing countries [2]. In fact, "Infertility belt" has been described in sub-Saharan African countries (SSA) where about 20-35 million couples are affected by their inability to give birth to a child $[3,4]$. It affects the social and psychological well-being of the couples with much more impact on the females compared to men, regardless of the cause of the Infertility $[5,6]$. It is a source of distress for couples as societal norms may equate infertility with a failure on a personal, interpersonal, emotional or social level [6]. In some societies, infertile women are excluded from certain social activities and traditional ceremonies, they are verbally or physically abused in their own homes, deprived of inheritance, sent back to their parents or even have their marriages dissolved or terminated [7]. 
Despite these psychosocial and health consequences very few infertility management programs exist in our environment thus limiting treatment options for those who seek medical interventions [5]. Several types of Assisted Reproductive Technologies (ARTs) have been introduced to reduce infertility problems, while accurate figures are difficult to obtain, there is little doubt that access to ART is extremely limited in all developing nations.

In Vitro Fertilization (IVF) is a method of assisted reproduction and may be the only option for couples who cannot have children through the natural biological means $[7,8]$. It is still considered to have an edge over adoption because in adoption, there is no genetic contribution by the couple but in IVF, couples contribute genetically or carry the baby [9]. In developing countries like Nigeria where fertility is valued to the extent that womanhood is defined as motherhood, IVF gives hope to the infertile even though only a few can afford it [10].

Unfortunately IVF is perceived as a new phenomenon shrouded in secrecy and stigma due to misconception, ignorance and socio-cultural factors [2]. It is perceived as abnormal, not natural, and worsened by the fact that IVF is seen as a costly treatment which is still beyond the reach of the teeming poor masses that are affected by the condition [11-13]. The high cost of IVF, misconception of what IVF is all about, religious belief/convictions cultural/traditional belief and failure of IVF treatment after paying so much money play prominent roles in Nigeria, and these are potential factors that may influence its utilization [12]. A crucial issue in the management of infertility, including ART, is that infertile couples need to have sufficient information so that they could make informed choices as to where and how they will be diagnosed and treated. In Nigeria, there has been a lot of researches on infertility but few on ARTs [5,13-19]. For the effective realization of various disease control measures instituted in any community, the knowledge/ awareness of the populace of the cause, available treatment options and people's views on it, is of immense importance [9]. Determining the perceptions and misperceptions of IVF among women of reproductive age group would be useful in providing additional insights that will guide in the choice of appropriate intervention measures in infertility treatment. This study therefore, aims to assess the awareness, perceptions and misperceptions of IVF among women of reproductive age group in Sokoto metropolis.

\section{Methods}

This was a cross-sectional descriptive study carried out in Wamakko Local Government Area (LGA), one of the urban LGAs of Sokoto state, Nigeria with an estimated total population of 206,917 . Using the formula for cross-sectional descriptive study and correcting for $10 \%$ non-response, a total of three hundred and six women of reproductive age group residing in the study area were enrolled using multistage sampling. Data was collected using a set of structured pretested interviewer administered questionnaire, adapted and modified from previous studies $[\mathbf{2}, \mathbf{1 1}, \mathbf{1 5}]$. The questionnaire consisted of 4 sections which included questions on the socio-demographic data of the respondents, their awareness, perception and misperceptions on IVF and willingness to utilize it. Data was cleaned, entered into and analyzed using IBM SPSS version 20. Chi-square test was used to compare categorical variables and multivariate analysis was done using the regression model to find out predictive variables for perception and willingness to utilize IVF. The level of statistical significance (alpha) for the test was set at $\mathrm{P} \leq 0.05$.

Permission to conduct the study was obtained from the Ethical review committee of the Usmanu Danfodiyo University Teaching Hospital, Sokoto; permission was obtained from community leaders while informed consent of respondents was sought after assurance of confidentiality of all information given.

\section{Results}

In this study the mean age of the respondents was $26.7 \pm 6.85$ years with a higher proportion 131 (45\%) of them being within 15-24 years (Table 1). Less than half had no children 139 (47.8\%), and just about half of the respondents 150 (51.5\%) were married (Table 1). A total (45.4\%) of the respondents had secondary education, and 127 (43.6\%) had tertiary education with only $16(5.5 \%)$ having no formal education (Table 1 ). Majority 216 (74.2\%) of the respondents have heard of IVF with $55(25.5 \%)$ of them getting their information from the mass media, while 49 (22.7\%) heard from friends (Figure 1).

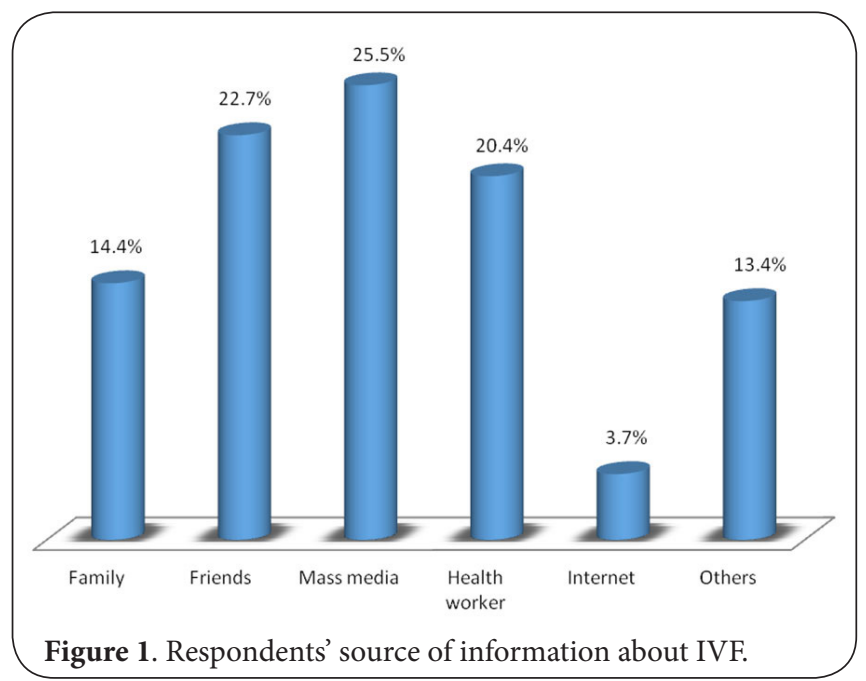

Majority of the respondents 153 (71.5\%) were aware that IVF services are available in Nigeria. Over two thirds of them knew that people with blocked tubes may require IVF as treatment option for infertility and another 134 (62\%) knew that IVF may be associated with failure (Table 2). Majority of the respondents $240(82.5 \%)$ felt IVF offers hope to infertile 
Oche et al. Journal of Reproductive Biology and Health 2018,

http://www.hoajonline.com/journals/pdf/2054-0841-6-1.pdf

doi: 10.7243/2054-0841-6-1

Table 1. Socio- demographic characteristics of the respondents.

\begin{tabular}{|c|c|c|}
\hline Variable & $\begin{array}{l}\text { Frequency } \\
n=291\end{array}$ & Percentage (\%) \\
\hline \multicolumn{3}{|l|}{ Age (years) } \\
\hline $15-24$ & 131 & 45.0 \\
\hline $25-34$ & 115 & 39.5 \\
\hline $35-44$ & 40 & 13.7 \\
\hline$\geq 45$ & 5 & 1.7 \\
\hline \multicolumn{3}{|l|}{ Mean age $=26.7 \pm 6.85$} \\
\hline \multicolumn{3}{|c|}{ Number of living children } \\
\hline 0 & 139 & 47.8 \\
\hline $1-2$ & 58 & 19.9 \\
\hline $3-4$ & 53 & 18.2 \\
\hline$\geq 5$ & 41 & 14.1 \\
\hline \multicolumn{3}{|l|}{ Tribe } \\
\hline Hausa & 152 & 52.2 \\
\hline Fulani & 58 & 19.9 \\
\hline Yoruba & 32 & 11.0 \\
\hline Igbo & 22 & 7.6 \\
\hline Others & 27 & 9.3 \\
\hline \multicolumn{3}{|l|}{ Religion } \\
\hline Islam & 251 & 86.3 \\
\hline Christianity & 40 & 13.7 \\
\hline \multicolumn{3}{|l|}{ Marital status } \\
\hline Single & 129 & 44.3 \\
\hline Married & 150 & 51.5 \\
\hline Divorced & 6 & 2.1 \\
\hline Widow & 6 & 2.1 \\
\hline \multicolumn{3}{|l|}{ Educational status } \\
\hline Informal & 16 & 5.5 \\
\hline Primary & 16 & 5.5 \\
\hline Secondary & 132 & 45.4 \\
\hline Tertiary & 127 & 43.6 \\
\hline \multicolumn{3}{|l|}{ Occupation } \\
\hline Full-time house wife & 63 & 21.6 \\
\hline Student & 134 & 46 \\
\hline Business & 50 & 17.2 \\
\hline Civil servant & 44 & 15.1 \\
\hline
\end{tabular}

Table 3. Respondents perception and misperceptions of IVF.

\begin{tabular}{lll}
\hline Variable & $\begin{array}{l}\text { Frequency } \\
\mathbf{n = 2 9 1}\end{array}$ & $\begin{array}{l}\text { Percentage } \\
\text { (\%) }\end{array}$ \\
\hline $\begin{array}{l}\text { Do you think IVF offers hope for } \\
\text { infertile couples? }\end{array}$ & \\
Yes & 240 & 82.5 \\
No & 51 & 17.5 \\
\hline $\begin{array}{l}\text { Do you think IVF is not a natural } \\
\text { process? }\end{array}$ & \\
Yes & 151 & 51.9 \\
No & 140 & 48.1 \\
\hline What do you think about IVF babies? & & \\
Normal and natural & 155 & 53.2 \\
Normal but not natural & 105 & 36.1 \\
Not normal and not natural & 31 & 10.7 \\
\hline Do you think IVF is too costly? & & \\
Yes & 236 & 81.1 \\
No & 55 & 18.9 \\
\hline Do you think IVF is not affordable/ & & \\
accessible? & & \\
Yes & 198 & 68 \\
No & 93 & 32 \\
\hline Do you think IVF babies should be & & \\
accepted by the society? & & \\
Yes & 236 & 81.1 \\
No & 55 & 18.9 \\
\hline Do you think babies born via IVF are & & \\
legitimate? & & \\
Yes & 208 \\
No & 83 \\
\hline Overall perception about IVF & 198 \\
Positive & 93 & \\
Negative & & \\
\hline & & \\
\hline
\end{tabular}

Table 2. Respondents' level of awareness of In Vitro Fertilization.

\begin{tabular}{llll}
\hline Variable & Yes n (\%) & No n (\%) & I don't know n (\%) \\
\hline Are IVF services available in Nigeria? & $153(71.5)$ & $61(28.7)$ & -- \\
These are causes of infertility that may necessitate IVF & & & \\
Abnormal menses & $136(63.3)$ & $19(8.8)$ & $60(27.9)$ \\
Blocked tubes & $150(69.8)$ & $13(6)$ & $52(24.2)$ \\
History of infections in the reproductive tract in women & $130(60.5)$ & $23(10.7)$ & $62(28.8)$ \\
History of infections in the reproductive tract in men & $89(41.6)$ & $43(20.1)$ & $82(38.3)$ \\
Previous use of contraceptive methods & $122(56.7)$ & $33(15.3)$ & $60(27.9)$ \\
Endocrine problems & $108(50.5)$ & $31(14.5)$ & $75(35)$ \\
Marriage at an advanced age & $96(44.7)$ & $51(23.7)$ & $68(31.6)$ \\
\hline These are forms of IVF & & & \\
Use of donor oocyte & $140(64)$ & $22(10.2)$ & $54(25)$. \\
Use of donor sperm & $141(65.3)$ & $7(3.2)$ & $68(31.5)$ \\
Use of donor zygote & $70(32.4)$ & $35(16.2)$ & $111(51.4)$ \\
Preservation of gamete & $72(33.5)$ & $24(11.2)$ & $119(55.3)$ \\
\hline IVF procedure may be associated with these problems & & & \\
Failure & $134(62.0)$ & $82(38.0)$ & -- \\
Genetic abnormalities in the baby & $135(62.5)$ & $81(37.5)$ & - \\
Death & $96(44.4)$ & $120(55.6)$ & -- \\
\hline
\end{tabular}


couples, however barely half 151 (51.9\%) believed it is not a natural process and about 36\% thought the babies from IVF are normal but not natural. Most respondents 236 (81.1\%) were opined that the procedure is too costly, not affordable and available ( $81.1 \%$ and $68 \%$ respectively (Table 3 ). Fifty one percent of the respondents would be willing to use IVF if the need arises among which 127 (84.7\%) will only use husband's sperm. Among those not willing to utilize IVF services, desire to conceive naturally $63(44.7 \%)$, religion $52(36.9 \%)$ and the high cost of the procedure $3(2.1 \%)$ were some of the reasons they gave (Table 4). The number of living children the respondents had was statistically significantly associated with their perception towards IVF; those with no children formed a higher proportion $(52.3 \%)$ of those with positive perception. Similarly most of the respondents that were aware of IVF 158 (79.4\%) had a positive perception towards the procedure. $(p=0.004)$ (Table 5). The respondents who were willing to utilize IVF were from the Islamic faith and this was found to be statistically significant $(p=0.04)$. Seventy-six $(50.7 \%)$ of the respondents who were willing to use IVF were within the age range of 15-24 years. There was a statistically significant association between awareness and perception $(p=0.023$ and $p=0.0001$ respectively) with willingness to utilize IVF services if the need arose (Table 6-8).

\section{Discussion}

Assisted Reproductive Technology (ART) has brought with it promising treatment modalities offering hope to infertile couples [20]. The findings in this study showed that about two thirds of the respondents were aware of IVF. This was similar to findings in Zaria and Ibadan, Nigeria where over $70 \%$ of the respondents were aware of IVF but studies from Kano, Bauchi, Akwa and Okija had less than $40 \%$ of the respondents being aware of IVF. Plausible reasons for the disparity may be due to the higher level of literacy among the respondents in the other studies who had better awareness $[2,9,11,13,15,18]$.

Table 4. Respondents' willingness to utilize IVF.

\begin{tabular}{lll}
\hline Variable & $\begin{array}{c}\text { Frequency } \\
\text { n-291 }\end{array}$ & $\begin{array}{l}\text { Percentage } \\
(\%)\end{array}$ \\
\hline Willing to use IVF if the need arises & & \\
Yes & 150 & 51.5 \\
No & 141 & 48.5 \\
\hline Method you would be willing to use & & \\
Donor sperm & 9 & 6.0 \\
Only husband's sperm & 127 & 84.7 \\
Donor oocyte & 13 & 8.7 \\
Donor zygote & 1 & 0.7 \\
\hline Reasons for not wanting to utilize IVF & & \\
services & & \\
Desire to conceive naturally & 63 & 44.7 \\
Religion & 52 & 36.9 \\
Culture & 8 & 5.7 \\
Will not be able to afford it & 3 & 2.1 \\
Others & 15 & 10.6 \\
\hline
\end{tabular}

Table 5. Respondents' background characteristics by their perception.

\begin{tabular}{|c|c|c|c|}
\hline \multirow[t]{2}{*}{ Variable } & \multicolumn{2}{|c|}{$\begin{array}{l}\text { Overall perception } \\
\mathrm{n}=291\end{array}$} & \multirow[t]{2}{*}{$\begin{array}{l}\text { Test statistic } \\
\text { \& p-value }\end{array}$} \\
\hline & $\begin{array}{l}\text { Positive, } \mathbf{n} \\
(\%)\end{array}$ & $\begin{array}{l}\text { Negative } \\
\text { n (\%) }\end{array}$ & \\
\hline \multicolumn{4}{|l|}{ Age group } \\
\hline $15-24$ & $95(47.7)$ & $36(39.1)$ & -- \\
\hline $25-34$ & $76(38.2)$ & $39(42.4)$ & \multirow{3}{*}{$\begin{array}{l}\chi^{2}=6.745 \\
p=0.076 \\
-\end{array}$} \\
\hline $35-44$ & $27(13.6)$ & $13(14.1)$ & \\
\hline$\geq 45$ & $1(0.5)$ & $4(4.3)$ & \\
\hline \multicolumn{4}{|c|}{ Number of living children } \\
\hline 0 & $104(52.3)$ & $35(38.0)$ & -- \\
\hline $1-2$ & $37(18.6)$ & $21(22.8)$ & -- \\
\hline $3-4$ & $37(18.6)$ & $16(17.4)$ & \multirow{2}{*}{$\begin{array}{l}\chi^{2}=8.866 \\
p=0.031\end{array}$} \\
\hline$\geq 5$ & $21(10.6)$ & $20(21.7)$ & \\
\hline \multicolumn{4}{|l|}{ Religion } \\
\hline Islam & $168(84.4)$ & $83(90.2)$ & \multirow{2}{*}{$\begin{array}{l}\chi^{2}=1.782 \\
\mathrm{p}=0.204\end{array}$} \\
\hline Christianity & $31(15.6)$ & $9(9.8)$ & \\
\hline \multicolumn{4}{|l|}{ Marital status } \\
\hline Single & $93(46.7)$ & $36(39.1)$ & \multirow{4}{*}{$\begin{array}{l}\text { Fischer's } \\
\text { exact } \\
\mathrm{p}=0.373\end{array}$} \\
\hline Married & $100(50.3)$ & $50(54.3)$ & \\
\hline Divorced & $3(1.3)$ & $3(3.3)$ & \\
\hline Widow & $3(1.5)$ & $3(3.3)$ & \\
\hline \multicolumn{4}{|c|}{ Educational status } \\
\hline Informal & $8(4)$ & $8(8.7)$ & \multirow{2}{*}{$\begin{array}{l}\chi^{2}=2.647 \\
p=0.163\end{array}$} \\
\hline Formal & 191(96) & $84(91.3)$ & \\
\hline \multicolumn{4}{|l|}{ Occupation } \\
\hline Unemployed & $132(66.3)$ & $65(70.7)$ & \multirow{2}{*}{$\begin{array}{l}\chi^{2}=0.537 \\
p=0.502\end{array}$} \\
\hline Employed & $67(33.7)$ & $27(29.3)$ & \\
\hline \multicolumn{4}{|c|}{ Ever heard of IVF } \\
\hline Yes & $158(79.4)$ & $58(63)$ & \multirow{2}{*}{$\begin{array}{l}\chi^{2}=8.795 \\
p=0.004\end{array}$} \\
\hline No & $41(20.6)$ & $34(37)$ & \\
\hline
\end{tabular}

In this study the commonest source of information was the mass media and friends; this was similar to the findings in Zaria, Awka, and Ibadan; however in Tehran where there was also a high level of awareness, the commonest source of information was from health centres. The difference could be attributed to low practice of IVF in Nigeria where very few centres provide IVF services $[\mathbf{2}, \mathbf{1 1}, \mathbf{1 8}, \mathbf{2 1}, \mathbf{2 2}]$.

This study showed that majority of the respondents (68\%) had a positive perception towards ART. A study in Benin City also had similar observation, where $70 \%$ of respondents had a positive perception of IVF [23]; however in Pakistan and Zaria a lower proportion of the study subjects felt it was acceptable as only $45 \%$ and $18.7 \%$ of the respondents respectively had a positive perception $[6,18]$. It is possible that the reasons for high acceptability of IVF among the women studied here could be because of their limited education on the entire IVF process thus not fully in grasp with the financial implications and issues surrounding the procedure which is in tandem with findings from a similar study [11]. The reasons for the lower perception in the other studies included cultural and religious beliefs with some people indicating that it is im- 
Oche et al. Journal of Reproductive Biology and Health 2018,

Table 6. Respondents' background characteristics by their willingness to use IVF.

\begin{tabular}{|c|c|c|c|}
\hline \multirow[t]{2}{*}{ Variable } & \multicolumn{2}{|c|}{$\begin{array}{l}\text { Willingness to } \\
\text { utilize IVF } n=291\end{array}$} & \multirow[t]{2}{*}{$\begin{array}{l}\text { Test statistics } \\
\text { \& p-value }\end{array}$} \\
\hline & Yes n (\%) & No $n(\%)$ & \\
\hline \multicolumn{4}{|l|}{ Age group } \\
\hline $15-24$ & $76(50.7)$ & $55(39)$ & \multirow{4}{*}{$\begin{array}{l}\text { Fischer's exact } \\
\mathrm{p}=0.211\end{array}$} \\
\hline $25-34$ & $52(34.7)$ & $63(44.7)$ & \\
\hline $35-44$ & $19(12.7)$ & $21(14.9)$ & \\
\hline$\geq 45$ & $3(2.0)$ & $2(1.4)$ & \\
\hline \multicolumn{4}{|c|}{ Number of living children } \\
\hline 0 & $81(54)$ & $58(41.1)$ & \multirow{4}{*}{$\begin{array}{l}\chi^{2}=6.326 \\
p=0.097\end{array}$} \\
\hline $1-2$ & $30(20)$ & $28(19.9)$ & \\
\hline $3-4$ & $22(14.7)$ & $31(22)$ & \\
\hline$\geq 5$ & $17(11.3)$ & $24(17)$ & \\
\hline \multicolumn{4}{|l|}{ Religion } \\
\hline Islam & $123(82)$ & $128(90.8)$ & \multirow{2}{*}{$\begin{array}{l}\chi^{2}=4.726 \\
\mathrm{p}=0.04\end{array}$} \\
\hline Christianity & $27(18)$ & $13(9.2)$ & \\
\hline \multicolumn{4}{|c|}{ Duration of marriage } \\
\hline $0-4$ & $21(28.8)$ & $23(27.7)$ & \multirow{5}{*}{$\begin{array}{l}\chi^{2}=8.208 \\
\mathrm{p}=0.084\end{array}$} \\
\hline $5-9$ & $26(35.6)$ & $31(37.3)$ & \\
\hline $10-14$ & $11(15.1)$ & $17(20.5)$ & \\
\hline $15-19$ & $5(6.8)$ & $10(12)$ & \\
\hline$\geq 20$ & $10(13.7)$ & $2(2.4)$ & \\
\hline \multicolumn{4}{|c|}{ Educational status } \\
\hline Informal & $6(4)$ & $10(7.1)$ & \multirow{2}{*}{$\begin{array}{l}\chi^{2}=1.337 \\
p=0.307\end{array}$} \\
\hline Formal & $144(96)$ & $131(92.9)$ & \\
\hline \multicolumn{4}{|l|}{ Occupation } \\
\hline Unemployed & $108(72.0)$ & $89(63.1)$ & \multirow{2}{*}{$\begin{array}{l}\chi^{2}=2,620 \\
p=0.132\end{array}$} \\
\hline Employed & $42(28.0)$ & $52(36.9)$ & \\
\hline \multicolumn{4}{|c|}{ Ever heard of IVF } \\
\hline Yes & $120(80)$ & $96(68.1)$ & \multirow{2}{*}{$\begin{array}{l}\chi^{2}=5.393 \\
p=0.023\end{array}$} \\
\hline No & $30(20)$ & $45(31.9)$ & \\
\hline \multicolumn{4}{|c|}{ Overall perception of IVF } \\
\hline Positive & $137(91.3)$ & $62(44)$ & \multirow{2}{*}{$\begin{array}{l}\chi^{2}=75.408 \\
p=0.0001\end{array}$} \\
\hline Negative & $13(8.7)$ & $79(56)$ & \\
\hline
\end{tabular}

Table 7. Respondents' likelihood of having a positive overall perception about IVF.

\begin{tabular}{|c|c|c|c|c|}
\hline \multirow[t]{2}{*}{ Variable } & \multirow[t]{2}{*}{ AOR } & \multicolumn{2}{|c|}{ 95\% CI for OR } & \multirow[t]{2}{*}{ p-value } \\
\hline & & Lower & Upper & \\
\hline \multicolumn{5}{|c|}{ Number of living children } \\
\hline 0 & 0.397 & 0.190 & 0.830 & 0.014 \\
\hline $1-2$ & 0.704 & 0.306 & 1.622 & 0.410 \\
\hline $3-4$ & 0.541 & 0.227 & 1.290 & 0.166 \\
\hline \multicolumn{5}{|c|}{ Have you ever heard of IVF? } \\
\hline Yes & 0.468 & 0.267 & 0.820 & 0.008 \\
\hline
\end{tabular}

moral to spend time and resources on extraordinary means of promoting births with the children from such births not accepted in the society [9].

In this study majority of the respondents thought IVF offered hope to infertile couples, however about half of them believed it is not a natural process, with most of them also feeling it was too costly. The study from Anambra and Ibadan, in Nigeria had similar findings as the thought of not conceiv-
Table 8. Likelihood of respondents willing to utilize IVF.

\begin{tabular}{lcccc}
\hline Variable & AOR & $\mathbf{9 5 \%}$ CI for OR & p-value \\
\hline $\begin{array}{l}\text { Religion } \\
\text { Islam }\end{array}$ & 2.022 & 0.893 & 4.580 & 0.091 \\
\hline $\begin{array}{l}\text { Have you ever heard of IVF? } \\
\text { Yes }\end{array}$ & 0.732 & 0.390 & 1.377 & 0.333 \\
\hline $\begin{array}{l}\text { Overall perception? } \\
\text { Positive }\end{array}$ & 0.078 & 0.040 & 0.152 & 0.000 \\
\hline
\end{tabular}

ing naturally and the high cost of the procedure were some of the factors that influenced the attitude and acceptability of IVF among those studied $[2,11]$. Factors that were statistically significantly associated with respondent's perception of In vitro Fertilization in this study were number of living children and awareness of IVF.

The study revealed that those without children formed the highest proportion (52\%) of those with positive perception towards IVF and about $79.4 \%$ of those with positive perception were those that have heard of In Vitro Fertilization before the survey. These findings are similar to those from Saudi Arabia where awareness and number of living children affected the perception of respondents towards ARTs [22]. In the survey carried out in Oxford in the USA, participants' general attitudes towards ART became progressively more positive as their level of awareness of ART increased. It is possible that this observed outcome is a manifestation of the mere exposure effect; that merely being exposed to infertility treatments is enough to increase acceptance and augment positive attitudes towards these treatments [24].

This study showed that about $51.5 \%$ of respondents were willing to use IVF services if the need arose and this is similar to the study in Pakistan where $50 \%$ of the respondents were willing to use the procedure [6]. The finding is however lower than that of Ibadan and Saudi Arabia where 59.3 and 70.3\% of the respondents respectively were willing to utilize the procedure $[11,22]$. The higher rates in these studies could probably be as a result of the fact that the studies were conducted among patients attending infertility clinic. The proportion of women willing to use IVF was however higher than was discovered in the studies from Okija and Kano where 37.2 and $7.6 \%$ of respondents respectively were willing to utilize ART $[9,15]$. Lower awareness rates and negative perception towards the procedure were the reasons for the lower proportion of women willing to use the IVF services in these studies. Among those willing to use IVF, majority preferred either their own gamete or that of their spouses; studies conducted in Okija, Ibadan and Zaria had similar observations and this could be attributed to the desire for genetic relationship with their offspring and also to avoid conflict within the marriage as to who the biological parent is $[\mathbf{9 , 1 1 , 1 8}]$. In contrast to this finding, the study from Greece showed that up to half of their respondents preferred to use 
donated gametes; 25 and in consonance with this, authors from developing countries found out that most respondents would accept donor gametes for their treatment only if it was kept private so that others can consider their offspring as biological $[18,25]$.

The factors that affected willingness to utilize IVF were religion, awareness and perception. About $80 \%$ of those willing to utilize IVF were aware of it however about two thirds of those who were not willing to use it were still aware of the procedure and despite their awareness they still had a negative perception. A number of studies similar to this, also found religion to have a profound influence on the acceptance of IVF $[8,15,20,22,26,27]$. The strong influence of religion could be seen in the explanations offered for declining IVF as well as the interesting fact that most respondents listed religious interventions as part of the reasons for their previous refusal of treatment. It has been observed that people who practised some religions and people who attend churches are less likely to accept IVF. This implies that some people would decline IVF because they had faith that God would provide them with babies without having to resort to any assisted conception intervention $[\mathbf{2 6 , 2 8 ]}$. Until all the misperceptions surrounding IVF are addressed, infertile couples will have to bear the burden of infertility with the resultant effects of more psychological disorders among the couples which have public health implications for marital harmony.

\section{Conclusion}

Societal institutions may be slow to cope with the ideas and practice of In vitro fertilization especially in Africa where the technology is still relatively new. The study showed that the level of awareness is above average but not from the appropriate source, this probably explains the poor perception even among those who have the knowledge. The study also showed that the major reason why some of those aware of IVF didn't accept it was because of the perceived abnormal or unnatural procedure. In addition, factors such as religion, culture, fertility status, cost, availability among others have been seen to affect perception and willingness to utilize In vitro fertilization. We therefore recommend that the government work closely with health care providers to explore ways to make IVF facilities more available and affordable and religious and traditional leaders should be involved through media campaigns in a drive to clear the misconceptions of the public regarding the procedure so that those who require it and can afford it will utilize.

\section{Competing interests}

The authors declare that they have no competing interests.

Authors' contributions

\begin{tabular}{|l|c|c|c|c|c|c|c|c|c|}
\hline Authors' contributions & OMO & JTA & GJG & RAO & NCO & ASU & FAA & OJO & ZMG \\
\hline Research concept and design & $\checkmark$ & -- & -- & -- & -- & $\checkmark$ & -- & -- & -- \\
\hline Collection and/or assembly of data & -- & -- & -- & -- & -- & -- & $\checkmark$ & $\checkmark$ & $\checkmark$ \\
\hline Data analysis and interpretation & $\checkmark$ & $\checkmark$ & $\checkmark$ & $\checkmark$ & -- & -- & -- & -- & -- \\
\hline Writing the article & $\checkmark$ & $\checkmark$ & $\checkmark$ & -- & $\checkmark$ & -- & -- & -- & $\checkmark$ \\
\hline Critical revision of the article & $\checkmark$ & $\checkmark$ & -- & -- & $\checkmark$ & $\checkmark$ & -- & -- & $\checkmark$ \\
\hline Final approval of article & $\checkmark$ & $\checkmark$ & $\checkmark$ & $\checkmark$ & -- & $\checkmark$ & $\checkmark$ & $\checkmark$ & $\checkmark$ \\
\hline Statistical analysis & $\checkmark$ & -- & $\checkmark$ & $\checkmark$ & -- & $\checkmark$ & -- & -- & $\checkmark$ \\
\hline
\end{tabular}

\section{Acknowledgements}

We wish to acknowledge all the research assistants who took part in the data collection and the participants for agreeing to take part in the study.

\section{Publication history}

Editor: Erich Cosmi, University of Padua, Italy.

Received: 01-Apr-2018 Final Revised: 09-May-2018

Accepted: 11-May-2018 Published: 18-May-2018

\section{References}

1. Cui W. Mother or nothing: the agony of infertility. Bull World Health Organ. 2010; 88:881-2. | Article | PubMed Abstract | PubMed FullText

2. Okafor $\mathrm{NI}$, Peter E and Obianuju U. Factors Affecting the Use of Ivf among Married Couples in Anambra State of Nigeria. International Journal of innovative research and development. 2015; 4:1-11. | Article

3. Okonofua FE. Infertility in Sub-Saharan Africa: In Okonofua, F.E and Odunsi, L. Contemporary Obstetrics and Gynaecology for Developing Countries. Women's Health and Action Research Centre. 2003; 128-56.

4. Vayena E, Rowe, P.J., Griffin, P.D., Daar, A.S., \& Merali, Z. . Infertility and Social Suffering: The Case for Art in Developing Countries. In Vayena, $E_{\text {, }}$ Rowe Pj, Griffin Pd, Eds. Current Practices and Controversies in Assisted
Reproduction. Report of a Meeting on Medical, Ethical and Social Aspects F Assisted Reproduction. Geneva, Switzerland: WHO. 2002; 15-21.

5. Omoaregba JO, James BO, Lawani AO, Morakinyo O and Olotu OS. Psychosocial characteristics of female infertility in a tertiary health institution in Nigeria. Ann Afr Med. 2011; 10:19-24. I Article I PubMed

6. Ali S, Sophie R, Imam AM, Khan FI, Ali SF, Shaikh A and Farid-ul-Hasnain S Knowledge, perceptions and myths regarding infertility among selected adult population in Pakistan: a cross-sectional study. BMC Public Health. 2011; 11:760. | Article | PubMed Abstract | PubMed FullText

7. Rani $\mathrm{K}$ and Paliwal S. A Brief Review on in Vitro Fertilization (Ivf): An Advanced and Miraculous Gateway for Infertility Treatments. World 
Oche et al. Journal of Reproductive Biology and Health 2018,

Journal of Pharmacy and Pharmaceutical Science. 2014; 3:647-58.

8. Ola TM. Assisted Reproductive Technology in Nigeria: Flawed or Favored. International Journal of Social Science and Humanity. 2012; 2:331-4.

9. Okwelogu IS, Azuike EC, Ikechebelu JI and Nnebue CK. In-Vitro Fertilization Practice: Awareness and Perceptions among Women Attending Fertility Clinics in Okija, Anambra State, Nigeria. Afrimedic Journal. 2012; 3. | Article

10. Widge A. Beyond Natural Conception: A Sociological Investigation of Assisted Reproduction with Special Reference to India [Thesis]. New Delhi, Jawaharlal Nehru University. 2000.

11. Bello FA, Akinajo OR and Olayemi O. In-vitro fertilization, gamete donation and surrogacy: perceptions of women attending an infertility clinic in Ibadan, Nigeria. Afr J Reprod Health. 2014; 18:127-33. | PubMed

12. Fabamwo $A O$ and Akinola OI. The understanding and acceptability of assisted reproductive technology (ART) among infertile women in urban Lagos, Nigeria. J Obstet Gynaecol. 2013; 33:71-4. | Article I PubMed

13. Idrisa A and Ojiyi E. Pattern of Infertility in North- Eastern Nigeria. Tropical Journal of Obstetrics and Gynaecology. 2000; 17:27-30.

14. Hollos M. Profiles of infertility in southern Nigeria: women's voices from Amakiri. Afr J Reprod Health. 2003; 7:46-56. | PubMed

15. Iliyasu Z, Galadanci HS, Abubakar IS, Bashir FM, Salihu HM and Aliyu $\mathrm{MH}$. Perception of infertility and acceptability of assisted reproduction technology in northern Nigeria. Niger J Med. 2013; 22:341-7. | PubMed

16. Nieuwenhuis SL, Odukogbe AT, Theobald S and Liu X. The impact of infertility on infertile men and women in Ibadan, Oyo State, Nigeria: a qualitative study. Afr J Reprod Health. 2009; 13:85-98. | PubMed

17. Omosun AO KO. Knowledge, Attitude and Practice Towards Child Adoption Amongst Women Attending Clinics in Lagos State, Nigeria. African Journal of Primary Health Care and Family Medicine. 2011; 3:25966.

18. Adebiyi GA, Ameh N, Avidime S and Muazu A. Awareness and Perception of Assisted Reproductive Technologies Amongst Women with Infertility in Northern Nigeria. Open Journal of Obstetrics and Gynaecology. 2011; 1:144- 8. | Pdf

19. Sule JO, Erigbali P and Eruom L. Prevalence of Infertility in Women in a South-Western Nigeria Community. African Journal of Biomedical Research. 2008; 11:225-7. | Pdf

20. Aluko-Arowolo SO and Ayodele SJ. The Effects of Native Culture and Religious Beliefs on Human Infertility \& Assisted Reproductive Treatment: A Focus on the ljebu People of Nigeria. 'African Journal of Social Sciences. 2014; 4:88-102.

21. Farnaz S and Mina J. Knowledge and Attitudes of Infertile Couples About Assisted Reproductive Technology. Iranian Journal of Reproductive Medicine. 2005; 3:90-4. | Pdf

22. Abolfotouh MA, Alabdrabalnabi AA, Albacker RB, Al-Jughaiman UA and Hassan SN. Knowledge, attitude, and practices of infertility among Saudi couples. Int J Gen Med. 2013; 6:563-73. | Article | PubMed Abstract I PubMed FullText

23. Asogun D, Tobin E, Esezobor A and Ishaq A. Child Adoption Amongst Women Attending Infertility Clinic in a Tertiary Hospital in South-South Nigeria. International Journal of Basic, Applied and Innovative Research. 2015; 4:130-7. | Article

24. Fortin C and Abele S. Increased Length of Awareness of Assisted Reproductive Technologies Fosters Positive Attitudes and Acceptance among Women. Int J Fertil Steril. 2016; 9:452-64. | Article | PubMed Abstract | PubMed FullText

25. Chliaoutakis JE. A relationship between traditionally motivated patterns and gamete donation and surrogacy in urban areas of Greece. Hum Reprod. 2002; 17:2187-91. | PubMed

26. Hareesh SG and Umadevi RH. Assisted Reproductive TechnologyMedical, Legal and Psychosocial Issues. Journal of Indian Academy of Forensic Medicine. 2009; 31:405-8. I Pdf

27. Olugbenga BA AW, Babatunde OA and Oke OS. Prevalence of Infertility and Acceptability of Assisted Reproductive Technology among Women
Attending Gynaecology Clinics in Tertiary Institutions in Southwestern Nigeria. Gynaecology and Obstetrics. 2014; 4:1-7. I Pdf

28. Abdallah SD and Zara M. Infertility and Social Suffering: The Case of Art in Developing Countries, Current Practices and Controversies in Assisted Reproduction, Report of a Meeting on "Medical, Ethical and Social Aspects of Assisted Reproduction". Geneva. 2001.

\section{Citation:}

Oche PM, Ango JT, Gana GJ, Oladigbolu RA, Okafoagu NC, Umar AS, Adam FA, Oluwatobi OJ and Gatawa AM. In vitro fertilization: Perceptions and misperceptions among women of reproductive age group in Sokoto, Nigeria. J Reprod Biol Health. 2018; 6:1. http://dx.doi.org/10.7243/2054-0841-6-1 